\title{
Coulomb static stress changes before and after the 23 October 2011 Van, eastern Turkey, earthquake $\left(M_{\mathrm{W}}=7.1\right)$ : implications for the earthquake hazard mitigation
}

\author{
M. Utkucu ${ }^{1}$, H. Durmuşs ${ }^{1}$ H. Yalçın ${ }^{1}$, E. Budakoğlu ${ }^{1}$, and E. Işık ${ }^{2}$ \\ ${ }^{1}$ Sakarya University, Department of Geophysics, Esentepe Campus, 54187, Serdivan, Sakarya, Turkey \\ ${ }^{2}$ Bitlis Eren University, Faculty of Engineering and Architecture, Department of Civil Engineering, 13000, Bitlis, Turkey \\ Correspondence to: M. Utkucu (mutkucu@sakarya.edu.tr)
}

Received: 14 November 2012 - Published in Nat. Hazards Earth Syst. Sci. Discuss.: Revised: 9 May 2013 - Accepted: 17 May 2013 - Published: 31 July 2013

\begin{abstract}
Coulomb stress changes before and after the 23 October 2011 Van, eastern Turkey, earthquake have been analysed using available data related to the background and the aftershock seismicity and the source faults. The coseismic stress changes of the background seismicity had slightly promoted stress over the rupture plane of the 2011 Van earthquake, while it yielded a stress shadow over the Gürpınar Fault which has been argued to have produced the 7 April 1646 Van earthquake. The stress shadow over the Gürpınar fault has become more pronounced following the occurrence of the 2011 Van earthquake, meaning that the repetition of the 1646 Van earthquake has been further suppressed. Spatial distribution and source mechanisms of the 2011 Van earthquake's aftershocks have been utilised to define four clusters with regard to their relative location to the mainshock rupture. In addition, the aftershock sequence covers a much broader area toward the northeast. Correlations between the observed spatial patterns of the aftershocks and the coseismic Coulomb stress changes caused by the mainshock are determined by calculating the stress changes over both optimally oriented and specified fault planes. It is shown here that there is an apparent correlation between the mainshock stress changes and the observed spatial pattern of the aftershock occurrence, demonstrating the usefulness of the stress maps in constraining the likely locations of the upcoming aftershocks and mitigating earthquake hazard.
\end{abstract}

\section{Introduction}

The general tectonic setting of Turkey is mainly affected by the northward movement of the Arabian and African plates with respect to the Anatolian plate, which results in a westward escape of the Anatolian plate (Fig. 1) (Şengör et al., 1985; Barka and Kadinsky-Cade, 1988; McClusky et al., 2000; Reilinger et al., 2006). Northward convergence of the Arabian plate causes a continental collision in eastern Turkey, which takes place along a suture zone known as Bitlis thrust zone (BTZ) (Fig. 1) (McClusky et al., 2000; Şengör et al., 2003). The convergence related deformation is mostly laterally transported to the Caucasus thrust fronts through the distributed NW-SE trending dextral faults and NE-SW trending sinistral faults within eastern Anatolia (Barka and Kadinsky-Cade, 1988; McClusky et al., 2000; Sandvol et al., 2003; Vernant et al., 2004; Reilinger et al., 2006).

The main tectonic features of the Lake Van area are the BTZ lying immediately south of Lake Van and a number of dextral and sinistral faults mentioned above (Figs. 1 and 2). Dextral Karayazı Fault, Tutak Fault, Erciş Fault zone (EFZ), Hasantimur Fault and Çaldıran Fault zone (ÇFZ) and sinistral Malazgirt, Süphan and Çakırbey faults (ÇF) are the members of the distributed strike-slip faulting lying close to Lake Van (Figs. 1 and 2) (Barka and Kadinsky-Cade, 1988; Adiyaman et al., 1998; Koçyiğit et al., 2011; AFAD, 2011; MTA, 2012).

The Lake Van basin is the eastern continuation of the Mus Ramp Basin and was separated from it by the Nemrut volcano complex (Şengör et al., 1985) (Figs. 1 and 2). The lake basin is almost completely bounded by steep boundary faults, 


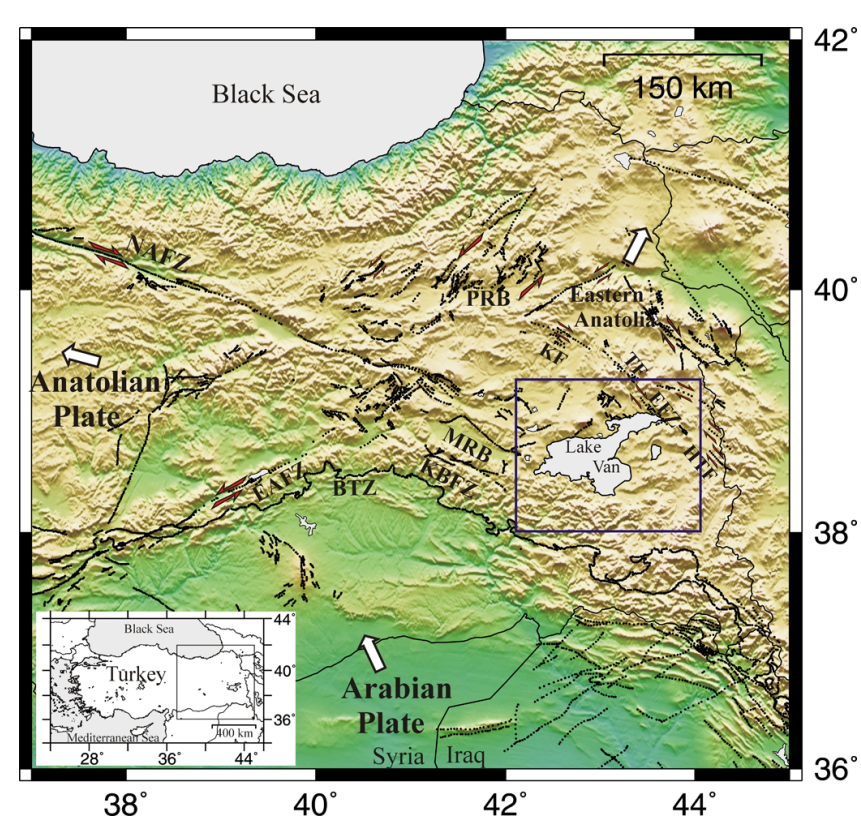

Fig. 1. Major tectonic elements of eastern Anatolia. Large rectangle encloses the map areas shown in Figs. 2, 3 and 4 and large arrows indicate relative plate motions. Extent of faults and relative plate motions are from MTA (2012) and Reilinger et al. (2006), respectively. NAFZ - North Anatolian Fault zone, EAFZ - East Anatolian Fault zone, BTZ - Bitlis thrust zone, MRB - Muş Ramp Basin, PRB - Pasinler Ramp Basin, KF - Karayazı Fault, TF - Tutak Fault, EFZ - Erciş Fault zone, HTF - Hasan Timur Fault, KBFZ - Kavakbaşı Fault zone.

namely the Northern Boundary Fault (NBF) and the Southern Boundary Fault (SBF) (Wong and Finckh, 1978; Wong and Degens, 1978; Litt et al., 2009; Toker, 2011). The earthquake focal mechanisms of the recent earthquakes in the area have indicated that the type of faulting along the boundary faults is mainly thrusting (Fig. 2) (Pinar et al., 2007; Utkucu, 2013a). Pinar et al. (2007) performed a stress tensor inversion of the available focal mechanisms and found that the stress regime was transpressive with a maximum compression axis roughly in the $\mathrm{N}-\mathrm{S}$ direction. The presence of active thrusting in the area was inarguably evidenced by the occurrence of the 23 October 2011 Van earthquake, which was produced by the Van fault (VF) (Utkucu et al., 2011; Emre et al., 2011; Akyüz et al., 2011; Gülen et al., 2012).

Over the past two decades, there has been a dramatic increase in the number of publications about earthquake interaction through static Coulomb stress changes (e.g. King et al., 1994; Stein et al., 1997; Harris, 1998; Stein, 1999; Steacy et al., 2004, Steacy et al., 2005a, b). Because static stress changes caused by an earlier earthquake can promote or delay subsequent earthquakes along nearby faults, earthquake stress changes can be utilised in the interpretation of future seismic hazards or earthquake probabilities (Stein et al., 1997; Nalbant et al., 2002; Utkucu et al., 2003; Parsons,

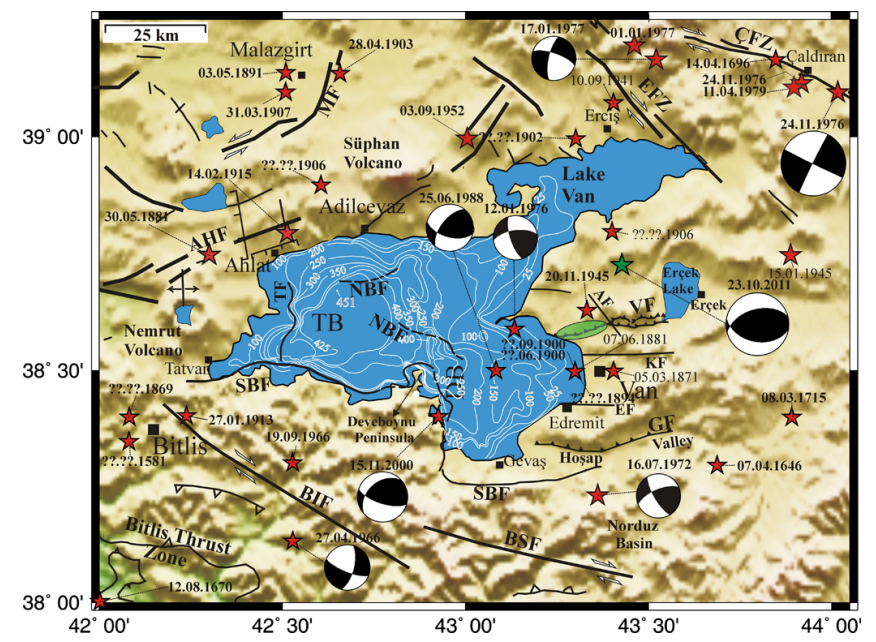

Fig. 2. Local tectonic features, epicentral distribution of large earthquakes (red and green stars) and available focal mechanisms (blackwhite beach balls) for the Lake Van area along with the bathymetry of Lake Van. Extent of faults are from Wong and Finckh (1978), Koçyiğit et al. (2011) and MTA (2012), focal mechanisms are from McKenzie (1972), Pınar (1995), Pınar et al. (2007), Utkucu (2013a) and USGS-NEIC and the bathymetry of Lake Van is from Wong and Degens (1978). See Table 2 for the hypocentral parameters of the earthquakes. The green shaded area indicates the area in which surface deformations were observed following the 2011 Van earthquake. NBF - Northern Boundary Fault, SBF - Southern Boundary fault, EFZ - Erciş Fault zone, ÇFZ - Çaldıran Fault zone, MF Malazgirt Fault, BIF - Bitlis Fault, BSF - Bahçesaray Fault, AHF Ahlat Fault, EF - Edremit Fault, KF - Kalecik Fault, AF - Alabayır Fault, DB - Deveboynu Basin, TB - Tatvan Basin, VF - Van Fault, GF - Gürpınar Fault.

2004). Moreover, near-real time estimations of the stress changes following a mainshock might be used as an emergency response tool for mitigating hazards caused by the ensuing aftershocks (Steacy et al., 2004; Lasocki et al., 2009; McCloskey and Nalbant, 2009). Therefore, simple Coulomb stress change calculations are of much importance for both our understanding of earthquake interactions and seismic hazard assessments.

The purpose of this study is to examine Coulomb static stress changes before and after the 23 October 2011 Van earthquake using all available data related to the seismicity and the source faults in the Lake Van area (Fig. 2, Table 1). We search for any clue from the 2011 Van earthquake and its largest aftershocks in the background stress changes and the stress changes caused by the mainshock alone.

\section{Seismicity of the Lake Van area}

Historical (Ambraseys and Finkel, 1995; Sinclair, 1999; Ambraseys, 2009; Albini et al., 2012) and instrumental period (Kalafat et al., 2007) seismicity studies and geological data recovered from the offshore and onshore lake sediments (Litt 
Table 1. Source parameters of the 23 October 2011 Van earthquake.

\begin{tabular}{lrrrrrrrrr}
\hline & $\begin{array}{r}\text { Lat. N } \\
\left({ }^{\circ}\right)\end{array}$ & $\begin{array}{r}\text { Lon. E } \\
\left({ }^{\circ}\right)\end{array}$ & $\begin{array}{r}\text { Depth } \\
(\mathrm{km})\end{array}$ & $\begin{array}{r}\text { Strike } \\
\left({ }^{\circ}\right)\end{array}$ & $\begin{array}{r}\text { Dip } \\
\left({ }^{\circ}\right)\end{array}$ & $\begin{array}{r}\text { Rake } \\
\left({ }^{\circ}\right)\end{array}$ & $\begin{array}{r}M_{\mathrm{O}} \\
\left(\times 10^{19} \mathrm{Nm}\right)\end{array}$ & $\begin{array}{r}\text { Maximum slip } \\
(\mathrm{m})\end{array}$ & Magnitude \\
\hline KOERI & 38.73 & 43.43 & 5 & & & & & & $M_{\mathrm{L}}=6.6$ \\
USGS $^{1}$ & 38.69 & 43.49 & 16 & 255 & 50 & 73 & 6.4 & & $M_{\mathrm{W}}=7.2$ \\
USGS $^{2}$ & 38.69 & 43.49 & 16 & 241 & 51 & 58 & 5.6 & & $M_{\mathrm{W}}=7.1$ \\
GCMT & 38.67 & 43.42 & 12 & 246 & 38 & 60 & 6.4 & & $M_{\mathrm{W}}=7.2$ \\
GFZ & 38.72 & 43.55 & 10 & 268 & 36 & 85 & 4.7 & & $M_{\mathrm{W}}=7.1$ \\
EMSC & 38.86 & 43.48 & 10 & 248 & 53 & 64 & 6.8 & & $M_{\mathrm{W}}=7.3$ \\
AT & & & & & & & 5.0 & 7.2 & $M_{\mathrm{W}}=7.2$ \\
HY & & & & & & & 5.16 & 4 & $M_{\mathrm{W}}=7.1$ \\
UT & & & & & & & 4.6 & 5.5 & $M_{\mathrm{W}}=7.1$ \\
\hline
\end{tabular}

KOERI $=$ Kandilli Observatory and Earthquake Research Institute; USGS ${ }^{1}=$ United States Geological Survey body-wave moment tensor solution; USGS ${ }^{2}=$ United States Geological Survey WPhase centroid moment tensor solution. GCMT = Global Centroid Moment Tensor Catalogue; GFZ = German Research Center for Geoscience; EMSC = European Mediterranean Seismological Center; AT = Atzori et al. (2011); $\mathrm{HY}=$ Hayes (2011); UT = Utkucu (2013a).

et al., 2009; Üner et al., 2010) indicate that the Lake Van area has been a seismically active region. Considering that the Lake Van area located in a region with complex tectonics and just north of a continental collision zone as indicated above, an active and damaging seismicity is not far-fetched. Table 2 tabulates the damaging earthquakes between the occurrence of notorious 7 April 1646 Van earthquake and 1860 and comprises all earthquakes with magnitude $M \geq 5.0$ from 1860 to the occurrence of the 2011 Van earthquake. The epicentre distribution of earthquakes in Table 2 is shown in Fig. 2 with available source mechanisms.

\section{The 23 October 2011 Van Earthquake $\left(M_{\mathrm{W}}=7.1\right)$}

The 23 October 2011 Van earthquake $\left(M_{\mathrm{W}}=7.1\right)$ generated by a rupture along the Van Fault (Figs. 2 and 3) (Emre et al., 2011; Akyüz et al., 2011; Utkucu et al., 2011; AFAD, 2011; Gülen et al., 2012). The earthquake caused heavy damage in Van city centre and in the town of Erciş as well as many villages between these settlements, leading to 604 deaths, 2608 injured and thousands of people left homeless (AFAD, 2011; Çelebi et al., 2013; CEDIM, 2011; Erdik et al., 2012). The large aftershock of the 9 November $2011\left(M_{\mathrm{W}}=5.7\right)$ resulted in additional damage, especially in the city centre of Van, and 40 more fatalities (Fig. 3). In total, the mainshock and the strong aftershock caused 17005 houses to be totally collapsed or damaged beyond repair, accounting for 1-2 billion USD economic loses (AFAD, 2011; Çelebi et al., 2013; CEDIM, 2011; Erdik et al., 2012).

The VF extends as two segments, lying roughly in the E-W direction for about $22 \mathrm{~km}$, between Lake Van and the Erçek Lake (Figs. 2 and 3) (Emre et al., 2011; Akyüz et al., 2011; AFAD, 2011). The earthquake produced no clear surface ruptures but some surface deformations along the western part of the fault trace for $10 \mathrm{~km}$, from the coast of Lake Van and eastward with vertical displacements of the order

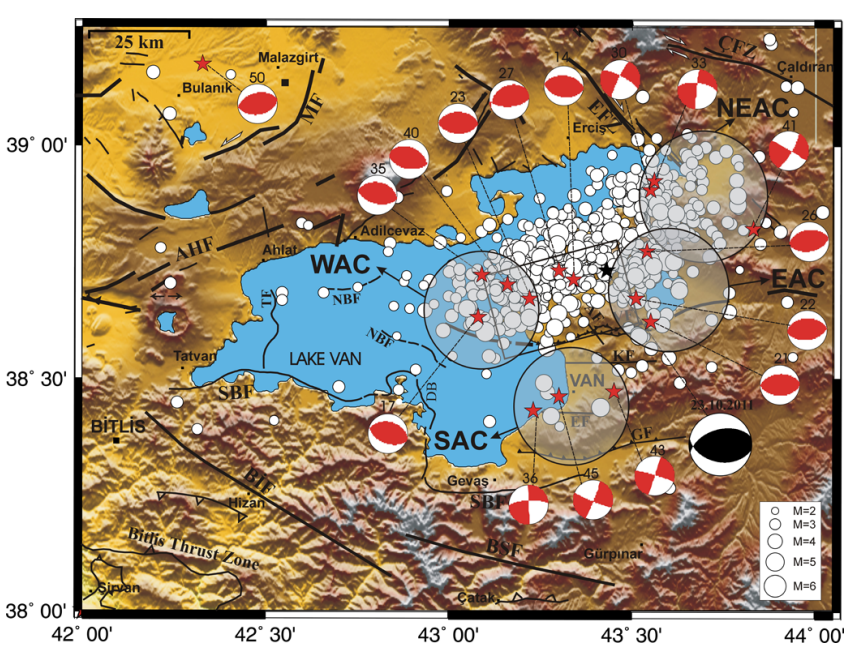

Fig. 3. Local tectonic features of the Lake Van area and the epicentre distribution of three day-long $M<4.6$ aftershocks of the 23 October 2011 Van earthquake (black star) along with the $M \geq 4.6$ aftershocks until April 2012. These aftershocks are represented with white circles excluding the $M \geq 4.6$ aftershocks with known source mechanisms (red-white beach balls), which are indicated by red stars. The black-white beach ball and the rectangle represent the source mechanism and surface projection of the rupture plane, respectively, of the 2011 Van earthquake used in the stress calculations. Four aftershock clusters identified regarding the source mechanisms are encircled and named as eastern (EAC), western (WAC), southern (SAC) and northeastern (NEAC) aftershock clusters. The aftershocks are taken from Kandilli Observatory and Earthquake Research Institute and USGS-NEIC catalogues. The aftershock focal mechanisms are from the GCMT catalogue. See caption of Fig. 2 for the other source of information and abbreviations and the text for details. 
Table 2. The earthquakes of the Lake Van area following 7 April 1646 Van earthquake, compiled from the catalogues given in Sect. 2 of the paper. Only damaging earthquakes are listed until 1860 and the earthquakes with $M \geq 5.0$ are listed after that date. See Fig. 2 for the epicentral distribution.

\begin{tabular}{|c|c|c|c|c|c|c|c|c|c|}
\hline No. & Date & $\begin{array}{l}\text { Macroseismic } \\
\text { Lat. N-Lon. E } \\
\left({ }^{\circ}\right)\end{array}$ & $\begin{array}{l}\text { Instrumental } \\
\text { Lat. N-Lon. E } \\
\left({ }^{\circ}\right)\end{array}$ & $\begin{array}{r}\text { Depth } \\
(\mathrm{km})\end{array}$ & Intensity & $M_{\mathrm{S}}$ & $M_{\mathrm{W}}$ & $m_{\mathrm{b}}$ & Remark \\
\hline 1 & 07.04 .1646 & $38.30-43.70$ & & & $X$ & 6.7 & & & Van \\
\hline 2 & ??.??.1669 & & & & & & & & Van \\
\hline 3 & 12.08 .1670 & $38.00-42.00$ & & & & 6.7 & & & Muş Bitlis \\
\hline 4 & 13.04 .1692 & & & & & & & & Adilcevaz \\
\hline 5 & 27.10 .1692 & & & & & & & & Van \\
\hline 6 & 14.04 .1696 & & & & & 6.8 & & & Çaldıran \\
\hline 7 & 10.06 .1696 & & & & & & & & Bitlis \\
\hline 8 & 26.03 .1701 & & & & VII & & & & Van-Pertek \\
\hline 9 & 27.01 .1705 & $38.70-41.70$ & & & IX & 6.7 & & & Bitlis \\
\hline 10 & 08.03 .1715 & $38.40-43.90$ & & & IX & 6.6 & & & Van \\
\hline 11 & ??.??.1869 & $38.40-42.10$ & & & VI & $\approx 5.0$ & & & Bitlis \\
\hline 12 & 05.03 .1871 & $38.50-43.40$ & & & & 5.5 & & & \\
\hline 13 & 30.05 .1881 & $38.75-42.30$ & & & & 6.3 & & & Ahlat area \\
\hline 14 & 07.06.1881 & $38.50-43.30$ & & & & $\approx 5.0$ & & & \\
\hline 15 & 10.02 .1884 & $38.40-42.10$ & & & & 6.1 & & & \\
\hline 16 & 03.05 .1891 & $39.15-42.50$ & & & & 6.0 & & & \\
\hline 17 & ??.??.1894 & $38.50-43.30$ & & & & $\approx 5.0$ & & & \\
\hline 18 & ??.06.1900 & $38.50-43.30$ & & & & $\approx 5.0$ & & & Van \\
\hline 19 & ??.09.1900 & $38.50-43.30$ & & & & $\approx 5.0$ & & & Van \\
\hline 20 & ??.??.1902 & $39.00-43.30$ & & & & $\approx 5.0$ & & & Erciş \\
\hline 21 & 28.04 .1903 & $39.14-42.65$ & & & & 7.0 & & & Malazgirt \\
\hline 22 & ??.??.1906 & $38.90-42.60$ & & & & $\approx 5.0$ & & & Nemrut \\
\hline 23 & ??.??.1906 & $38.80-43.40$ & & & & $\approx 5.0$ & & & \\
\hline 24 & 31.03 .1907 & $39.10-42.50$ & & & & 5.2 & & & Malazgirt \\
\hline 25 & 27.01.1913 & & $38.38-42.23$ & 10 & & 5.4 & & & \\
\hline 26 & 14.02 .1915 & & $38.80-42.50$ & $?$ & & 5.6 & & & \\
\hline 27 & 10.09 .1941 & $39.13-43.12$ & $39.07-43.40$ & 20 & & $5.9-6.0$ & & & Erciş \\
\hline 28 & 15.01 .1945 & $38.47-43.30$ & $38.75-43.89$ & 10 & & $4.9-5.0$ & & & Van \\
\hline 29 & 20.11 .1945 & $38.44-43.49$ & $38.63-43.33$ & 10 & & $5.5-5.8$ & & & Van \\
\hline 30 & 03.09 .1952 & & $39.00-43.00$ & 12 & & 5.5 & & & \\
\hline 31 & 27.04 .1966 & & $38.13-42.52$ & 40 & & 5.6 & & 5.1 & \\
\hline 32 & 19.09 .1966 & $39.16-41.53$ & $38.30-42.52$ & 35 & & & & 5.2 & \\
\hline 33 & 16.07 .1972 & & $38.23-43.36$ & 46 & & & & 5.0 & Gevaş \\
\hline 34 & 12.01.1976 & & $38.59-43.13$ & 36 & & & & 5.0 & Van \\
\hline 35 & 24.11 .1976 & & $39.10-44.02$ & 10 & & 7.3 & & & Çaldıran \\
\hline 36 & 24.11 .1976 & & $39.12-43.92$ & 33 & & & & 5.0 & \\
\hline 37 & 01.01.1977 & & $39.20-43.46$ & 24 & & & & 5.0 & \\
\hline 38 & 17.01.1977 & & $39.17-43.52$ & 33 & & & & 5.0 & Çaldıran \\
\hline 39 & 11.04.1979 & & $39.11-43.90$ & 34 & & & & 5.0 & \\
\hline 40 & 25.06 .1988 & & $38.50-43.08$ & 50 & & & & 5.3 & Van \\
\hline 41 & 15.11 .2000 & & $38.40-42.92$ & 23 & & & 5.7 & & Van \\
\hline 42 & 23.10 .2011 & & $38.73-43.43$ & 5 & & & 7.1 & & Van \\
\hline
\end{tabular}

of $10 \mathrm{~cm}$. The geometric patterns of these deformations and the other morphological features observed in the field indicate that the faulting was reverse (the northern fault block is hanging wall) and did not reach to surface (Emre et al., 2011).

Table 1 provides hypocentral and source parameters of the earthquake, estimated by different seismological organisations and institutes. The source mechanism solutions for the earthquakes suggest that the earthquake was due to reverse faulting. Teleseismic waveform inversions by Hayes (2011) and Utkucu (2013a) and geodetic inversion by Atzori et al. (2011) using InSAR data indicated that the major rupture propagated unilaterally to SW for about $30 \mathrm{~km}$ 


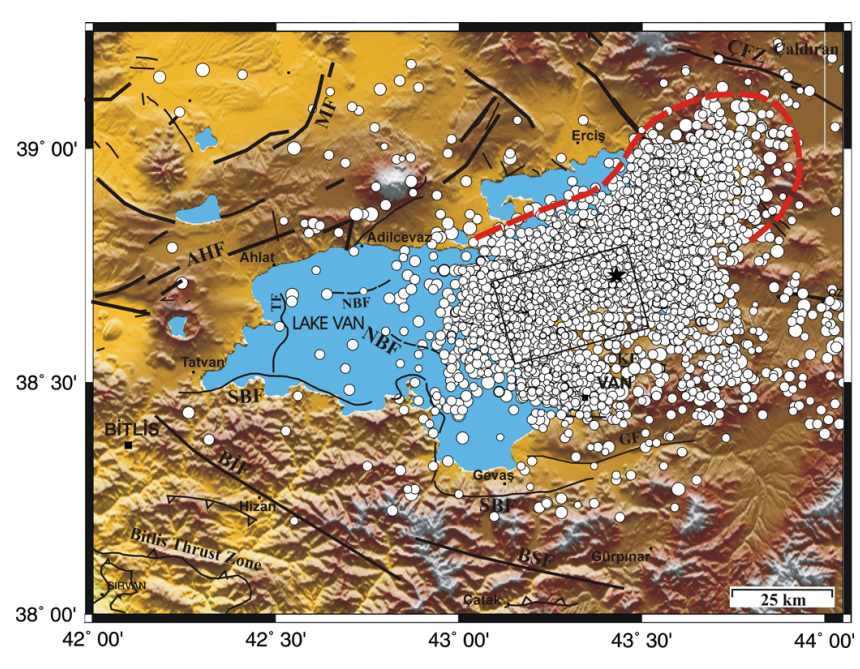

Fig. 4. Epicentre distribution of the aftershocks (white filled circles) occurred until April 2012 and provided by Kandilli Observatory and Earthquake Research Institute along with local tectonic features. The black star and the rectangle denote the epicentre and surface projection of the rupture plane of the 2011 Van earthquake used by Utkucu (2013a), respectively. Note that the dense aftershock epicentres cover much broader area toward NE due to a lobe of aftershock epicentres (broken red line) protruding outward. See caption of Fig. 2 for the active fault references and abbreviations and text for details.

and updip from the hypocentre with peak slip in the range 4 to $7 \mathrm{~m}$.

The earthquake was followed by a long-lasting and effective aftershock activity that comprises $51 M_{\mathrm{W}} \geq 4.6$ shocks until the end of April 2012, as reported by KOERI and USGS-NEIC (Table 3). Epicentral distribution of the $72 \mathrm{~h}$ long $M<4.6$ aftershocks along with all $M_{\mathrm{w}} \geq 4.6$ aftershocks given in Table 3 is depicted in Fig. 3. Also shown in Fig. 3 is the available source mechanism in the GCMT catalogue for the $M_{\mathrm{W}} \geq 4.6$ aftershocks (see Table 3 for the source parameters). Without defining any magnitude threshold, the aftershocks available in KOERI catalogue until April 2012 are shown in Fig. 4. The reason for the separate showing of the aftershocks in two maps is to effectively compare the stress perturbation caused by the 2011 Van earthquake with the spatial pattern of the aftershocks distribution. The aftershock activity not only has been dreadful for the local people but also inflicted additional damage, particularly exemplified by the 9 November $2011\left(M_{\mathrm{W}}=5.7\right)$ aftershock (Fig. 3). As apparent from both epicentre location and the source mechanism solution of this aftershock, it occurred on a different fault.

From the aftershock distribution and the available source mechanisms shown in Figs. 3 and 4, the following spatial patterns could be interpreted. Four clusters are apparent for the $M_{\mathrm{w}} \geq 4.6$ aftershocks regarding their relative location with the mainshock rupture and source mechanisms (Fig. 3). The eastern and western clusters with thrust faulting mechanisms are interpreted along the VF beyond the mainshock rupture. The southern and north eastern clusters with strike-slip faulting mechanisms are defined along the other faults lying close to the VF, exemplifying off-fault aftershocks. Another pattern appears from Fig. 4, which indicates that the dense aftershock epicentres cover much broader area toward NE, especially for the north of the VF.

If the damaging the 9 November $2011\left(M_{\mathrm{W}}=5.7\right)$ aftershock has been triggered by the mainshock stress changes or not and if the interpreted patterns of the aftershocks are connected with the pattern of the coseismic stress changes are the issues that are investigated in the present study for the ultimate purpose of earthquake hazard mitigation.

\section{Coulomb stress changes analysis}

Having compiled the available background seismicity in both historical and instrumental periods before the 2011 Van earthquake, it is now examined whether coseismic Coulomb failure stress changes related to the background seismicity might have triggered the 2011 Van earthquake and if Coulomb stress changes related to the mainshock itself could explain the occurrence of aftershocks and their pattern. The Coulomb failure stress changes due to the previous shock or shocks are resolved onto the fault plane of the interested earthquake by taking into account its strike, dip and rake angles in the stress calculations. Coulomb failure stress change $\left(\Delta \sigma_{\mathrm{f}}\right)$ can be simply expressed as

$\Delta \sigma_{\mathrm{f}}=\Delta \tau+\mu^{\prime} \Delta \sigma_{\mathrm{n}}$,

where $\Delta \tau$ and $\Delta \sigma_{\mathrm{n}}$ represent the changes in the shear and the normal stresses over the target fault plane, respectively, while $\mu^{\prime}$ is the apparent coefficient of the friction (Harris, 1998; Steacy et al., 2005a), which includes the unknown effect of pore fluid pressure and has been postulated to vary in the range 0.2-0.8 (Stein, 1999). The selection of value of $\mu^{\prime}$ has been pointed out to be not crucial in affecting the pattern of change in Coulomb failure stress (King et al., 1994; Steacy et al., 2004). We have used $\mu^{\prime}=0.4$ in our stress calculations and base them on the coseismic elastic dislocation modelling of the earthquakes (Okada, 1992) by assuming earthquake ruptures as rectangular dislocation surfaces in an elastic half-space having Young's modulus of $8 \times 10^{5}$ bar and Poisson's ratio of 0.25 . Coulomb 3.2 software is used to estimate Coulomb failure stress changes (Lin and Stein, 2004; Toda et al., 2005).

To explore stress changes before the 2011 Van earthquake, the 1646 Van earthquake has been selected as a time threshold in the past and we have used only $M \geq 6.0$ earthquakes, with the exception of the 2000 Gevas earthquake $\left(M_{\mathrm{W}}=\right.$ 5.6), in the Coulomb stress change modelling. The time threshold is chosen because there is a large gap for reporting of earthquakes in the historical sources before the 17th century (Albini et al., 2012) and the 1646 Van earthquake has 
Table 3. The hypocentral and source parameters of the $M \geq 4.6$ aftershocks of the 23 October 2011 Van earthquake, compiled from the catalogues of Kandilli Observatory and Earthquake Research Institute, GCMT and USGS-NEIC.

\begin{tabular}{|c|c|c|c|c|c|c|c|c|c|c|c|c|}
\hline No & $\begin{array}{l}\text { Date } \\
\text { (GMT) }\end{array}$ & $\begin{array}{l}\text { Origin time } \\
\text { (GMT) }\end{array}$ & $\begin{array}{l}\text { Latitude } \mathrm{N} \\
\left({ }^{\circ}\right)\end{array}$ & $\begin{array}{l}\text { Longitude E } \\
\left({ }^{\circ}\right)\end{array}$ & $\begin{array}{r}\text { Depth } \\
(\mathrm{km})\end{array}$ & $M_{\mathrm{W}}$ & $M_{\mathrm{L}}$ & $m_{\mathrm{b}}$ & $\begin{array}{l}\text { Strike } \\
\left({ }^{\circ}\right)\end{array}$ & $\begin{array}{l}\text { Dip } \\
\left(^{\circ}\right)\end{array}$ & $\begin{array}{l}\text { Rake } \\
\left({ }^{\circ}\right)\end{array}$ & $\begin{array}{l}\text { CMT depth } \\
(\mathrm{km})\end{array}$ \\
\hline 1 & 23.10 .2011 & 10.48 .17 & 38.7513 & 43.5952 & 9 & & 5.2 & 5.6 & & & & \\
\hline 2 & 23.10 .2011 & 10.52 .05 & 38.7600 & 43.2500 & 7 & & - & 4.8 & & & & \\
\hline 3 & 23.10 .2011 & 10.56 .49 & 38.8137 & 43.4462 & 5 & & 5.5 & 5.6 & & & & \\
\hline 4 & 23.10 .2011 & 11.00 .14 & 38.5900 & 43.5200 & 10 & & - & 4.6 & & & & \\
\hline 5 & 23.10 .2011 & 11.00 .29 & 38.6000 & 43.1000 & 10 & & - & 5.2 & & & & \\
\hline 6 & 23.10 .2011 & 11.10 .44 & 38.4385 & 43.4148 & 11 & & 4.7 & 5.0 & & & & \\
\hline 7 & 2310.2011 & 11.16 .26 & 38.7400 & 43.3400 & 10 & & - & 4.7 & & & & \\
\hline 8 & 23.10 .2011 & 11.32 .41 & 38.8095 & 43.3003 & 5 & & 5.5 & 5.7 & & & & \\
\hline 9 & 23.10 .2011 & 12.03 .10 & 38.7762 & 43.1970 & 5 & & - & 4.7 & & & & \\
\hline 10 & 23.10 .2011 & 12.42 .09 & 38.7300 & 43.1900 & 5 & & - & 4.8 & & & & \\
\hline 11 & 23.10 .2011 & 15.24 .31 & 38.4900 & 43.2600 & 15 & & & 4.8 & & & & \\
\hline 12 & 23.10 .2011 & 15.58 .00 & 38.6600 & 43.3300 & 18 & & & 4.6 & & & & \\
\hline 13 & 23.10 .2011 & 16.05 .08 & 38.7520 & 43.5530 & 5 & & & 4.5 & & & & \\
\hline 14 & 23.10 .2011 & 18.10 .45 & 38.7102 & 43.3382 & 5 & & 5.0 & 5.1 & $100 / 275$ & $45 / 45$ & $93 / 87$ & 20.9 \\
\hline 15 & 23.10 .2011 & 18.53 .48 & 38.7760 & 43.3507 & 8 & & 4.9 & 4.9 & & & & \\
\hline 16 & 23.10 .2011 & 19.06 .06 & 38.7868 & 43.2960 & 5 & & 4.9 & 4.8 & & & & \\
\hline 17 & 23.10 .2011 & 20.45 .34 & 38.6345 & 43.0775 & 5 & 6.0 & 5.7 & 6.0 & $281 / 111$ & $40 / 50$ & $82 / 96$ & 12.0 \\
\hline 18 & 23.10 .2011 & 22.21 .30 & 38.6200 & 43.0700 & 5 & & - & 4.8 & & & & \\
\hline 19 & 24.10 .2011 & 04.43 .01 & 38.6500 & 43.2300 & 5 & & & 4.7 & & & & \\
\hline 20 & 24.10 .2011 & 05.54 .57 & 38.6400 & 43.3000 & 10 & & & 4.7 & & & & \\
\hline 21 & 24.10 .2011 & 08.28 .26 & 38.6200 & 43.5500 & 3 & & & 4.8 & $92 / 265$ & $45 / 45$ & $94 / 86$ & 22.0 \\
\hline 22 & 24.10 .2012 & 08.49 .21 & 38.6700 & 43.5100 & 7 & & & 4.9 & $268 / 82$ & $41 / 49$ & $94 / 86$ & 20.2 \\
\hline 23 & 24.10 .2011 & 15.28 .06 & 38.6737 & 43.2243 & 5 & & 4.8 & 4.9 & $269 / 93$ & $44 / 46$ & $87 / 93$ & 18.5 \\
\hline 24 & 24.10 .2011 & 23.55 .14 & 38.7400 & 43.5600 & 5 & & & 4.6 & & & & \\
\hline 25 & 25.10 .2011 & 02.33 .52 & 38.7552 & 43.1905 & 5 & & & 4.1 & & & & \\
\hline 26 & 25.10 .2011 & 14.55 .08 & 38.7733 & 43.5468 & 5 & 5.6 & 5.4 & 5.7 & $264 / 79$ & $43 / 47$ & $94 / 86$ & 14.4 \\
\hline 27 & 26.10 .2011 & 03.16 .18 & 38.7300 & 43.300 & 5 & & & 4.7 & $102 / 239$ & $36 / 32$ & $127 / 66$ & 30.6 \\
\hline 28 & 28.10 .2011 & 08.48 .08 & 38.6974 & 43.6293 & 6 & & & 4.2 & & & & \\
\hline 29 & 29.10 .2011 & 18.45 .48 & 38.6252 & 43.1742 & 3 & & & 4.5 & & & & \\
\hline 30 & 29.10 .2011 & 22.24 .22 & 38.8985 & 43.5503 & 5 & & 5.3 & 5.0 & $298 / 206$ & $77 / 82$ & $172 /-14$ & 19.4 \\
\hline 31 & 02.11 .2011 & 04.34 .20 & 38.8735 & 43.5695 & 5 & & 4.8 & & & & & \\
\hline 32 & 02.11 .2011 & 13.24 .02 & 38.8565 & 43.5778 & 5 & & 4.7 & 4.6 & & & & \\
\hline 33 & 06.11 .2011 & 02.43 .12 & 38.9243 & 43.5650 & 5 & & 4.9 & 4.7 & $277 / 186$ & $64 / 87$ & $-176 /-26$ & 15.8 \\
\hline 34 & 07.11 .2011 & 15.53 .51 & 38.6882 & 43.6307 & 4 & & 4.7 & 4.8 & & & & \\
\hline 35 & 08.11 .2011 & 22.05 .51 & 38.7242 & 43.0870 & 6 & 5.2 & 5.5 & 5.6 & $280 / 104$ & $37 / 53$ & $87 / 92$ & 21.2 \\
\hline 36 & 09.11 .2011 & 19.23 .33 & 38.4295 & 43.2342 & 5 & 5.6 & 5.6 & 5.6 & $267 / 358$ & $72 / 89$ & $179 / 18$ & 13.5 \\
\hline 37 & 09.11.2011 & 19.30 .11 & 38.4200 & 43.2800 & 4 & & & 4.8 & & & & \\
\hline 38 & 12.11 .2011 & 18.20 .01 & 38.6300 & 43.2200 & 5 & & & 4.6 & & & & \\
\hline 39 & 14.11 .2011 & 16.47 .16 & 38.6500 & 43.0500 & 5 & & & 4.7 & & & & \\
\hline 40 & 14.11 .2011 & 22.08 .16 & 38.6973 & 43.1578 & 8 & & 5.2 & 5.3 & $296 / 98$ & $40 / 51$ & $104 / 78$ & 17.3 \\
\hline 41 & 18.11 .2011 & 17.39 .43 & 38.8235 & 43.8323 & 5 & & & 4.9 & $31 / 300$ & $77 / 88$ & $2 / 167$ & 16.7 \\
\hline 42 & 22.11 .2011 & 03.30 .35 & 38.6100 & 43.2900 & 2 & & & 4.6 & & & & \\
\hline 43 & 30.11 .2011 & 00.47 .21 & 38.4740 & 43.4530 & 4 & & 5.0 & 4.9 & $287 / 17$ & $86 / 89$ & $179 / 4$ & 28.4 \\
\hline 44 & 03.12 .2011 & 01.30 .54 & 38.8700 & 43.7900 & 5 & & & 4.7 & & & & \\
\hline 45 & 04.12 .2011 & 22.15 .02 & 38.4600 & 43.3000 & 5 & & & 4.7 & $112 / 22$ & $84 / 87$ & $-177 /-6$ & 24.3 \\
\hline 46 & 06.12 .2011 & 02.55 .59 & 38.8527 & 43.6217 & 3 & & & 4.5 & & & & \\
\hline 47 & 27.12.2011 & 19.18 .52 & 38.8900 & 43.7900 & 5 & & & 4.7 & & & & \\
\hline 48 & 20.01 .2012 & 09.57 .36 & 38.7185 & 43.5102 & 6 & & & 4.7 & & & & \\
\hline 49 & 17.02 .2012 & 09.32 .58 & 38.7000 & 43.2100 & 4 & & & 4.7 & & & & \\
\hline 50 & 26.03.2012 & 10.35 .32 & 39.1700 & 42.3300 & 5 & 5.0 & & - & $82 / 256$ & $44 / 46$ & $94 / 86$ & 19.5 \\
\hline 51 & 24.06 .2012 & 20.07 .22 & 38.7495 & 43.6143 & 9 & & & 4.5 & & & & \\
\hline
\end{tabular}


Table 4. Rupture parameters for the earthquakes selected for the Coulomb stress change modelling in the Lake Van area. S1 and S2 stand for first and second segment of the earthquake rupture under interest. See Fig. 2 for the epicentral distribution.

\begin{tabular}{|c|c|c|c|c|c|c|c|c|c|c|c|c|c|c|}
\hline \multirow[t]{2}{*}{ No. } & \multirow[t]{2}{*}{ Date } & \multirow[t]{2}{*}{$\begin{array}{l}\text { Epicentre } \\
\text { Lat. N-Lon. E } \\
\left({ }^{\circ}\right)\end{array}$} & \multirow[t]{2}{*}{$M_{\mathrm{S}}$} & \multirow[t]{2}{*}{$M_{\mathrm{W}}$} & \multicolumn{2}{|c|}{$\begin{array}{c}\text { Strike } \\
\left({ }^{\circ}\right)\end{array}$} & \multicolumn{2}{|c|}{$\begin{array}{l}\text { Dip } \\
\left({ }^{\circ}\right)\end{array}$} & \multicolumn{2}{|c|}{$\begin{array}{c}\text { Rake } \\
\left({ }^{\circ}\right)\end{array}$} & $\begin{array}{c}\text { Fault } \\
\text { length } \\
(\mathrm{km})\end{array}$ & \multicolumn{2}{|c|}{$\begin{array}{l}\text { Fault } \\
\text { width } \\
(\mathrm{km})\end{array}$} & \multirow[t]{2}{*}{$\begin{array}{r}\text { Slip } \\
(\mathrm{m})\end{array}$} \\
\hline & & & & & S1 & $\mathrm{S} 2$ & S1 & $\mathrm{S} 2$ & S1 & $\mathrm{S} 2$ & $\mathrm{~S} 1$ & S1 & S2 & \\
\hline 1 & 07.04 .1646 & $38.30-43.70$ & 6.7 & & \multicolumn{2}{|c|}{265} & \multicolumn{2}{|c|}{50} & \multicolumn{2}{|c|}{73} & $38^{\mathrm{a}}$ & \multicolumn{2}{|c|}{23.50} & $1.7^{\mathrm{a}}$ \\
\hline 2 & 12.08 .1670 & $38.00-42.00$ & 6.7 & & \multicolumn{2}{|c|}{303} & \multicolumn{2}{|c|}{85} & \multicolumn{2}{|c|}{175} & 38 & \multicolumn{2}{|c|}{18.07} & $1.4^{\mathrm{a}}$ \\
\hline 3 & 14.04 .1696 & & 6.8 & & 105 & 117 & 85 & 85 & 176 & 176 & $42^{\mathrm{b}} \quad 36^{\mathrm{b}}$ & 24 & 24 & Variable $e^{b}$ \\
\hline 4 & 08.03 .1715 & $38.40-43.90$ & 6.6 & & \multicolumn{2}{|c|}{255} & \multicolumn{2}{|c|}{50} & \multicolumn{2}{|c|}{73} & $35^{\mathrm{c}}$ & \multicolumn{2}{|c|}{30} & Variable $^{\mathrm{c}}$ \\
\hline 5 & 30.05 .1881 & $38.75-42.30$ & 6.3 & & \multicolumn{2}{|c|}{250} & \multicolumn{2}{|c|}{85} & \multicolumn{2}{|c|}{5} & $21^{\mathrm{a}}$ & \multicolumn{2}{|c|}{10.04} & $0.5^{\mathrm{a}}$ \\
\hline 6 & 03.05 .1891 & $39.15-42.50$ & $6.0-6.3$ & & \multicolumn{2}{|c|}{250} & \multicolumn{2}{|c|}{85} & \multicolumn{2}{|c|}{5} & $21^{\mathrm{a}}$ & \multicolumn{2}{|c|}{10.04} & $0.5^{\mathrm{a}}$ \\
\hline 7 & 28.04 .1903 & $39.14-42.65$ & 7.0 & & 204 & 251 & 85 & 85 & 5 & 5 & $20 \quad 21$ & 18.07 & 18.07 & $1.5^{\mathrm{a}}$ \\
\hline 8 & 10.09 .1941 & $39.07-43.40$ & 6.0 & & \multicolumn{2}{|c|}{145} & \multicolumn{2}{|c|}{85} & & & $14^{\mathrm{a}}$ & 10. & & $0.3^{\mathrm{a}}$ \\
\hline 9 & 24.11 .1976 & $39.10-44.02$ & 7.3 & & 105 & 117 & 85 & 85 & 176 & 176 & $42^{\mathrm{d}} \quad 36^{\mathrm{d}}$ & 24 & 24 & Variable ${ }^{c}$ \\
\hline 10 & 15.11 .2000 & $38.40-42.92$ & & 5.7 & & & & & & & $9^{\mathrm{a}}$ & 5 & & $0.32-0.24$ \\
\hline 11 & 23.10 .2011 & $38.73-43.43$ & & 7.1 & & & & & & & $35^{\mathrm{e}}$ & 31 & & Variable $\mathrm{e}^{\mathrm{e}}$ \\
\hline
\end{tabular}

${ }^{a}$ Fault lengths and slip values are determined from the empirical relations of Wells and Coppersmith (1994). ${ }^{\mathrm{b}}$ The same rupture model as the 1976 Çaldıran earthquake obtained by Utkucu et al. (2002) is assumed. ${ }^{\mathrm{c}}$ The same rupture model as the 2011 Van earthquake obtained by Utkucu (2013a) is assumed. ${ }^{\mathrm{d}}$ The rupture model obtained by Utkucu et al. (2002) is used. ${ }^{\mathrm{e}}$ The rupture model obtained by Utkucu (2013a) is used.

been known for its widespread and relatively well-reported damage distribution (Ambraseys and Finkel, 1995; Sinclair, 1999; Ambraseys, 2009). It should also be noted that there is another gap in the reporting between 1715 and 1860, as can be clearly seen from Table 2 . As there is no way for the destructive $M \geq 6.5$ earthquakes to be neglected in the historical sources after the start of 18th century, this gap could be for the relatively smaller magnitude earthquakes, which have smaller rupture length and insignificant stress perturbations in the crust as compared to earthquakes with magnitude of the order of $M=7$. So, 11 earthquakes, including the 1646 and 2011 earthquakes, are used in the modelling (Table 4).

The rupture parameters (strike, dip, rake and slip values of the faulting) for these earthquakes are summarised in Table 4. The rupture parameters and source faults of the earthquakes after the 1903 Malazgirt earthquakes are defined from the published studies (Utkucu et al., 2002; Utkucu, 2013a). As for the rupture parameters of the historical earthquakes, including the 1903 Malazgirt earthquake, the following methodology is used. We first assigned the most likely source faults for the historical earthquakes. The strike of the faulting is assigned from the trace of the source fault on the active fault map (Figs. 2 and 3). Dip and rake angle of the relevant earthquake is decided considering the type of the faulting. If the source fault is strike-slip faulting then the dip angle is vertical or nearly vertical in the range $80^{\circ} t o 90^{\circ}$ (we use $85^{\circ}$ for that sort of faulting) and the rake angle is between $\pm 170^{\circ}$ and $180^{\circ}$ for right-lateral faults and between $0^{\circ}$ and $\pm 10^{\circ}$ for left-lateral faults. If the faulting is reverse, then we assign dip and rake angles similar to the 2011 Van earthquake and the strike is measured from the active fault map. The rupture length and slip amplitude of the earthquake are defined regarding the magnitude of the relevant earthquake using the empirical relationships given by Wells and Coppersmith (1994) and assuming homogeneous fault slip. For example, the 1903 Malazgirt earthquake ruptured the two-segmented Malazgirt Fault (MF), the northern segment strikes $204^{\circ}$ and the southern segment strikes $251^{\circ}$, as measured from the active fault map (Figs. 2 and 3) (MTA, 2012; Şaroğlu, 1985). When the fault is left-lateral strike slip then its dip and rake angles are assigned as $85^{\circ}$ and $5^{\circ}$, respectively. Regarding its large magnitude, the earthquake is considered to rupture the MF all along its length, which is measured $40 \mathrm{~km}$ from the active fault map (Figs. 2 and 3). Then, assuming homogeneous slip, the slip amplitude is estimated as $1.5 \mathrm{~m}$ from the empirical relationships. The seismogenic thickness starts from the earth's surface and is assumed to be $20 \mathrm{~km}$ for all earthquakes.

Coulomb stress changes merely due to the 2011 Van earthquake have been calculated to compare the stress pattern of the mainshock with the occurrence of the aftershocks and their distribution pattern. The stress changes have been estimated over the optimally oriented strike-slip and reverse faults and individually over the selected faults as well. Note that stress change calculations over an optimally oriented fault require definition of the regional stress field by means of principal stress axes orientations. We use the regional stress field defined by Pınar et al. (2007) along with the regional stress field determined in the study, using both background seismicity, and the aftershocks with available source parameters (Tables 2 and 3).

\section{Results}

The map view of the calculated stress patterns before the 2011 Van earthquake have been shown in Fig. 5. The stress 

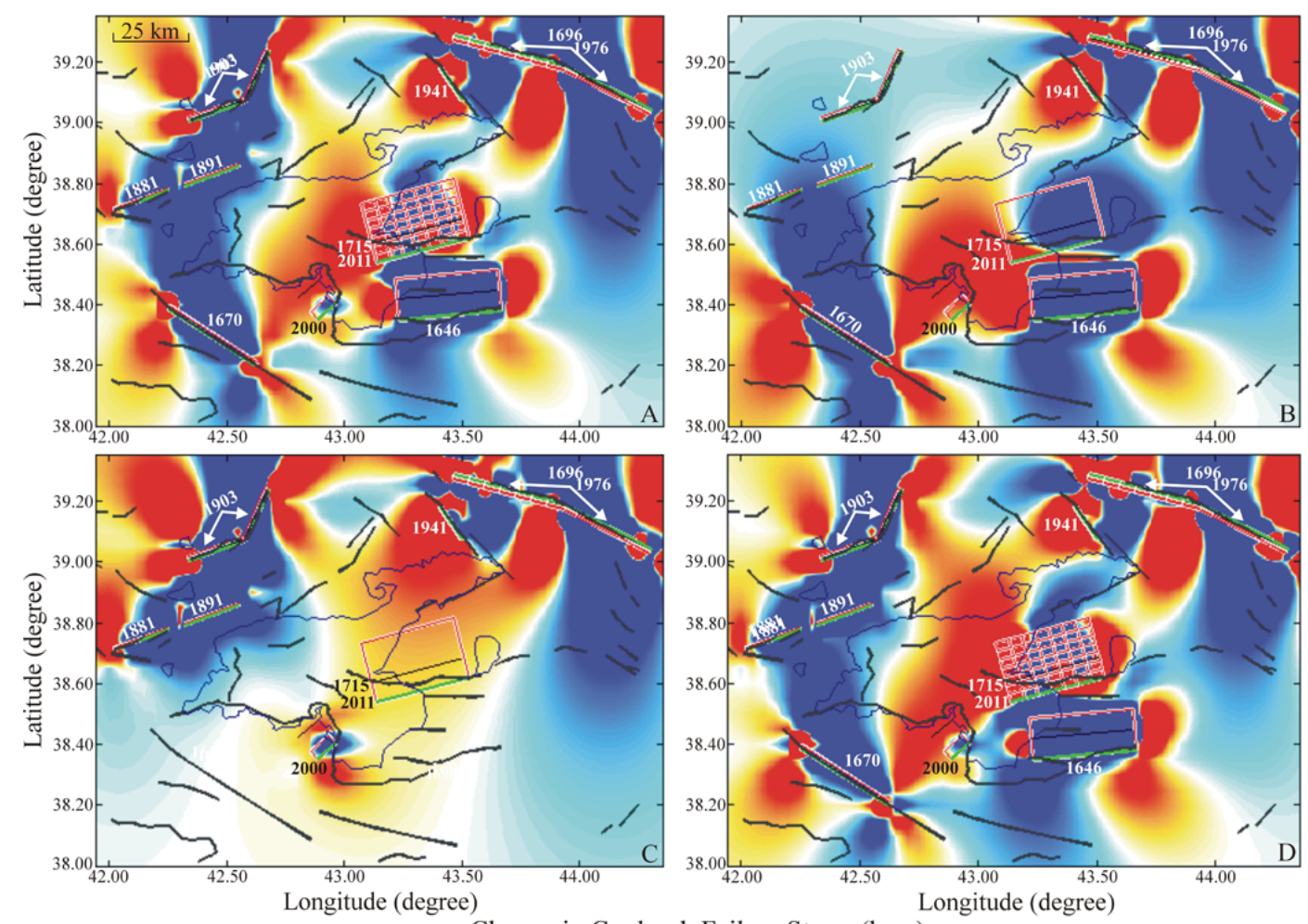

Change in Coulomb Failure Stress (bars)

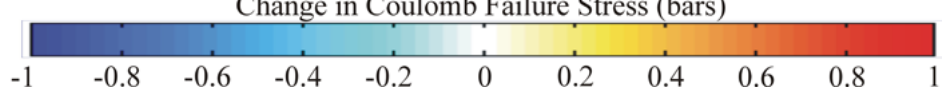

Fig. 5. Maps of Coulomb stress changes due to the background seismicity in the Lake Van area before and after the 23 October 2011 Van earthquake. The stress changes due to (a) all earlier earthquakes, (b) the earthquakes before 1715 Van earthquake and (c) the earthquakes after 1715 and before 2011 have been resolved onto the 2011 Van earthquake's fault plane (strike $255^{\circ}$, dip $50^{\circ}$, rake $73^{\circ}$ ). (d) The stress changes following the 2011 Van earthquake calculated over the 1646 Van earthquake's fault, the Gürpinar fault (strike $265^{\circ}$, dip $50^{\circ}$, rake $73^{\circ}$ ). See Table 4 for the list of earthquakes in the background seismicity and their rupture parameters and the caption of Fig. 2 for the active fault references.

patterns in Fig. 5 have been imaged at a depth of $9 \mathrm{~km}$, which is approximately equal to half the seismogenic thickness in the Lake Van area. Enhancement and reduction in the stresses are represented with red and blue colours, respectively. The selection of the source faults for the historical earthquakes (the 1903 Malazgirt and the earlier earthquakes) will be discussed below. The stress changes due to all of the earlier earthquakes, the earthquakes before the 1715 earthquake and the earthquakes following the 1715 earthquakes have been resolved onto the 2011 Van earthquake rupture plane (e.g. over the VF) and shown in Fig. 5a, b and c. Figure 5d illustrates the state of the stress changes following the occurrence of the 2011 Van earthquake and reflects the stress changes caused by the earlier earthquakes including the 2011 Van earthquake. The stress changes in Fig. 5d have been computed over the Gürpınar fault (GF) (e.g. the source fault of the 1646 Van earthquake).

Figure 6 reflects the Coulomb stress changes merely due to the 2011 Van earthquake along with the epicentral distribution of the $M_{\mathrm{W}} \geq 4.6$ aftershocks (Table 3). In Fig. 6a and $\mathrm{b}$, the stress changes have been resolved onto the optimally oriented strike-slip and thrust faults using the regional stress field defined by Pinar et al. (2007). In Fig. 6c-f, the stress changes have been estimated over the representative fault planes of the aftershock clusters located in the east, west, south and northeast of the mainshock rupture. The stress changes have been resolved onto the fault planes with strike of $266^{\circ}$, dip of $45^{\circ}$ and rake of $90^{\circ}$ (e.g. eastern extend of the VF) for the eastern cluster (Fig. 6c), onto the fault planes with strike of $285^{\circ}$, dip of $41^{\circ}$ and rake of $90^{\circ}$ (e.g. western offshore extend of the VF) for the western cluster (Fig. 6d), onto the fault planes with strike of $270^{\circ}$, dip of $70^{\circ}$ and rake of $180^{\circ}$ (e.g. EF) for the southern cluster (Fig. 6e) and onto the fault planes with strike of $298^{\circ}$, dip of $77^{\circ}$ and rake of $-172^{\circ}$ (e.g. faults related NW-SE trending EFZ in the east of Lake Van) for the NE cluster (Fig. 6f). 

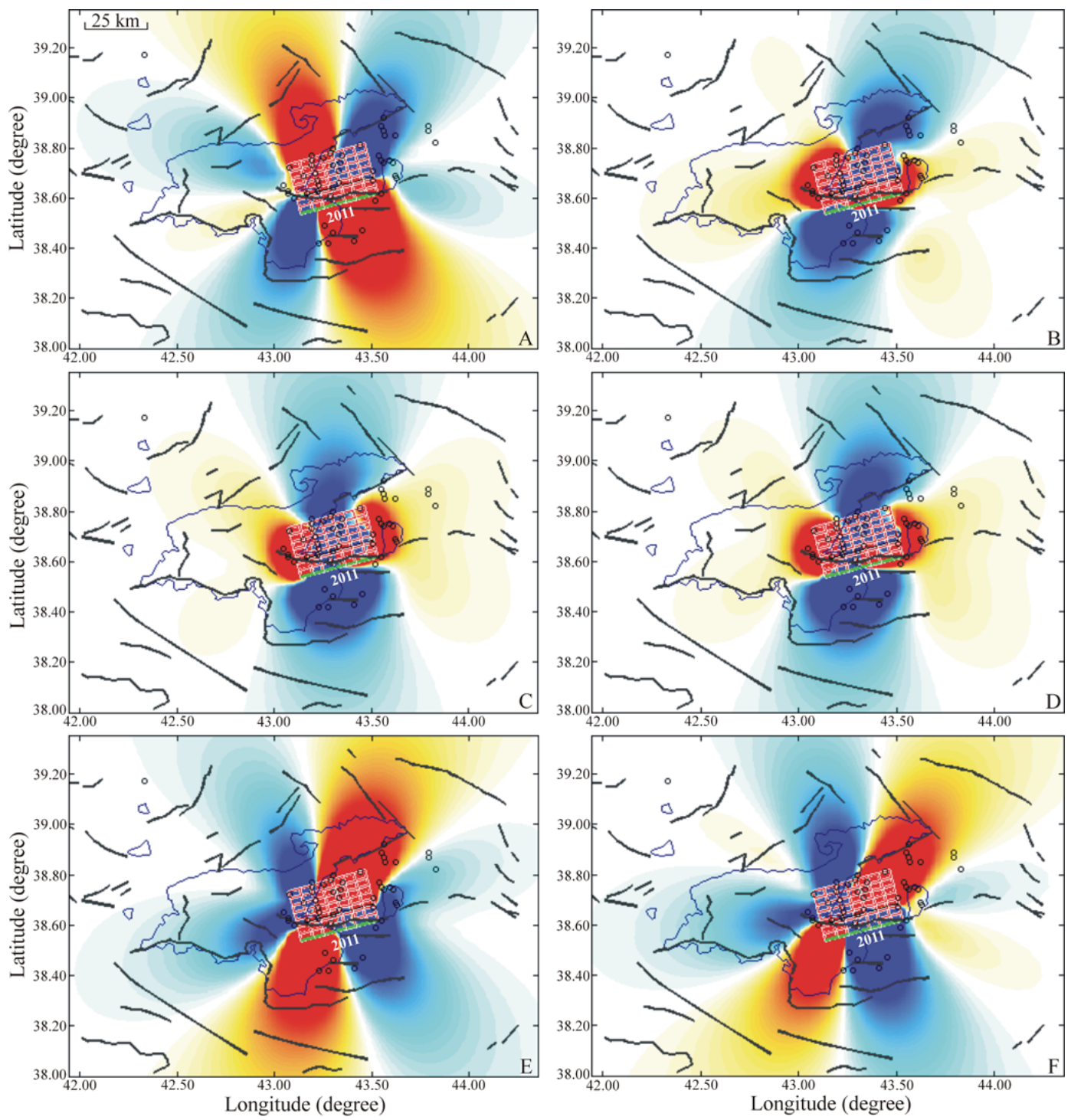

Change in Coulomb Failure Stress (bars)

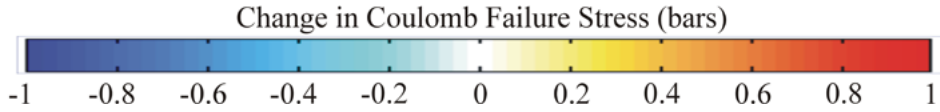

Fig. 6. Maps of Coulomb stress changes caused by the 2011 Van earthquake calculated over the optimally oriented (a) strike-slip and (b) thrust faults along with over the representative fault planes of the four aftershock clusters discussed in the text and shown in Fig. 3.The stress changes have been resolved onto the representative fault plane of (c) the eastern cluster (strike $266^{\circ}$, dip $45^{\circ}$ and rake $90^{\circ}$ ), (d) the western cluster (strike $285^{\circ}$, dip $41^{\circ}$ and rake $90^{\circ}$ ), (e) the southern cluster (strike $270^{\circ}$, dip $70^{\circ}$ and rake $180^{\circ}$ ) and (f) the for the north eastern (strike $298^{\circ}$, dip $77^{\circ}$ and rake $-172^{\circ}$ ). The open circles denote the epicentres of the $M \geq 4.6$ aftershocks listed in Table 3 . See caption of Fig. 2 for the active fault references.

\section{Discussion}

\subsection{Selection of the source faults}

Macroseismic effects of the 1646 and 1715 Van earthquakes suggest that they occurred in the east-southeast of Lake Van with the 1646 Van earthquake having a possible source fault located more southward than the 1715 Van earthquake (Ambraseys, 2009; Sinclair, 1999). Utkucu (2013a) argued that the 1715 Van earthquake was a predecessor of the 2011 earthquake because of that it had caused damage in town of Erciş, where no reporting of damage for the 1646 earthquake. Additionally, the 1646 Van earthquake caused damage in town of Gevaş and in the area south-southeast of that town, where no damage was reported after the 1715 and 2011 Van earthquakes. So, the Van and Gürpınar faults have been assigned as the source faults of the 1715 and 1646 Van earthquakes, respectively. 
The damage area of the large 1670 Muş-Bitlis and 1705 Bitlis earthquakes covered W-SW of Lake Van (Ambraseys, 2009). However, the former caused damage in town of Hizan in the south of Lake Van while the latter, in particular, yielded destruction in the west of Bitlis. Therefore, the srike-slip Bitlis fault has been considered as the likely source of the 1670 earthquake (Fig. 2), while the Kavakbaşı Fault (see Fig. 1 for its location) has been assigned as the source of the 1705 Bitlis earthquake. The Kavakbaşı Fault zone remains outside of the study area. Therefore, the 1705 Bitlis earthquake has not been included in the stress changes calculations.

The similarity in their damage patterns suggests that the 1976 Çaldıran earthquake was a recurrence of the 1696 Çaldıran earthquake and both were produced by the ÇF. The 1881 and 1891 Adilcevaz earthquakes obviously affected the area between Nemrut and Süphan volcanoes (Clayton, 1881; Ambraseys, 2009). As seen from Fig. 2, the 1891 Adilcevaz earthquake was located near the MF. However, its destruction mainly occurred in the town of Adilcevaz, while relatively slight damage was reported for the town of Malazgirt (Ambraseys, 2009). The earthquake also caused a rise in the level of Jilgöl, a small lake a few kilometers NW of Adilcevaz. Therefore, it was proposed that the earthquake had taken place somewhere south of the MF (Albini et al., 2012). The fact that lake Jilgöl is located near the NE extreme of the Ahlat fault and the 1881 earthquake effected south of Adilcevaz prompted us to assign Ahlat fault as the source of both the 1881 and 1891 earthquakes with the latter shock rupturing northeastern part of the fault.

As we discuss in this section, the source faults for the larger shock of the 1646 and 1715 Van and 1696 Çaldıran earthquakes are more or less known (Utkucu, 2013a). For smaller historical shocks in 1881 and 1891, they do not have much influence (with the exception of their local influence on the MF or occurrence of the 1903 Malazgirt earthquake) on the overall stress picture shown in Fig. 5. It would be reasonable to think that the stress changes shown in Fig. 5 could vary with different assignments of the source faults for the historical earthquakes. Nevertheless, the overall stress picture would not change much by holding a different point of view for the selection of the source faults of the smaller shocks, especially for the area east of Lake Van that we focus on in the present study.

\subsection{Stress changes before and after the 2011 Van earthquake}

Figure 5a indicates that the Van fault is partly stressed and partly under the stress shadow due to all of the earlier earthquake occurrences. Since we do not include stress load caused by the plate motions in the interseismic period it seems that the coseismic stress changes merely do not overwhelm the stress decrease caused by the 1715 Van earthquake over the Van fault (remember that the 1715 Van earthquake has been regarded as the predecessor of the 2011 Van earthquake). When the stress changes due to the earthquakes before and after the 1715 Van earthquake have been individually resolved onto the VF, we see that stress decrease prevails over the 1715 Van earthquake rupture plane due the earthquakes (the 1646 Van earthquake in particular) in the previous period (Fig. 5b), while a slight stress increase has resulted due to the earthquakes in the latter period (Fig. 5c). These suggest that in addition to the tectonic loading due to the plate motions, the 2011 Van earthquake's rupture plane has been stressed due to the coseismic stress changes caused by the earthquakes after the 1715 Van earthquake. A stress change calculation for the 1976 Çaldıran earthquake alone (not shown here) has yielded that the stress increase over the 2011 Van earthquake in Fig. 5c was mainly caused by the 1976 Çaldıran earthquake.

Figure 5d reflects state of the stress following the 2011 Van earthquake. The stress changes estimated over the rupture planes are similar to the 1646 Van earthquake's rupture plane (e.g. the GF) using all earthquakes in Table 4. Three large earthquakes with a magnitude of the order of 7 occurred in the eastern half of the study area during the historical period (the 1646 and 1715 Van earthquakes and 1696 Çaldıran earthquake). Both the 1696 Çaldıran and the 1715 Van earthquakes recurred. The 1976 Çaldıran earthquake was a recurrence of the 1696 Çaldıran earthquake while the 2011 Van earthquake was a repetition of the 1715 Van earthquake. So, the 1646 Van earthquake has not recurred. This is why the stress changes have been calculated over the GF, the source fault assigned for the 1646 Van earthquake. As is apparent from Fig. 5d, the GF is almost completely under the stress shadow of the earlier shocks. Since we do not include stresses due to the tectonic loading in our stress change computations, the state of stress without the 1646 Van earthquake has also been computed (not shown in Fig. 5), which yielded almost similar results. A computation of stress changes using only the 2011 Van earthquake has resulted in that the GF was again exposed to a stress decrease. Therefore, it is reasonable to claim that the occurrence of the 2011 Van earthquake decreased likelihood of an earthquake along the GF or suppressed repetition of the 1646 Van earthquake.

\subsection{The spatial pattern of the aftershocks versus the mainshock stress changes}

We now examine if the interpreted spatial patterns of the aftershock distribution will have any relation with the estimated stress changes of the 2011 Van mainshock. Figure $6 \mathrm{a}$ depicts the Coulomb stress changes due to the 2011 Van earthquake over the optimally oriented strike-slip faults along with the epicentral distribution of the $M_{\mathrm{W}} \geq 4.6$ aftershocks. It is clear that the stress changes following the mainshock explain the southern aftershock cluster with strikeslip faulting mechanisms but could not explain the northeastern aftershock clusters with the same faulting mechanisms 
(Fig. 3). Interestingly, it partly explains the eastern and western aftershock clusters with thrust faulting. When the stress changes resolved onto the optimally oriented thrust faults as shown in Fig. 6b, it is seen that the clusters with thrust faulting mechanisms (e.g. eastern and western aftershock clusters) fall into the areas of stress increase while the strike-slip clusters fall into the areas of the stress decrease. As indicated above the stress changes shown in Fig. 6a and $b$ have been estimated using the regional stress field defined by Pinar et al. (2007), who obtained a stress regime with predominantly strike-slip faulting (azimuth and plunge pair for $\sigma_{1}, \sigma_{2}$ and $\sigma_{3}$ are $\left(335^{\circ}, 16^{\circ}\right),\left(255^{\circ}, 32^{\circ}\right)$ and $\left(42^{\circ}, 53^{\circ}\right)$, respectively). Using the available source mechanisms for the background seismicity (Fig. 2) and for the aftershocks of the 2011 Van earthquake (Fig. 3; Table 3), Utkucu et al. (2013b) carried out stress tensor inversion and obtained a stress regime with predominant thrusting (azimuth and plunge pair for $\sigma_{1}, \sigma_{2}$ and $\sigma_{3}$ are $\left(124^{\circ}, 23^{\circ}\right),\left(20^{\circ}, 30^{\circ}\right)$ and $\left(245^{\circ}, 51^{\circ}\right)$, respectively). The stress changes have been estimated using the regional stress field defined by Utkucu et al. (2013b) resulted in virtually the same stress changes shown in Fig. $6 a-b$, suggesting moderate variations of the regional stress regime do not result in much change in the stress calculations.

Note that the stress changes over the optimally oriented faults shown in Fig. 6a-b explain the aftershock clusters with the exception of the northeastern aftershock cluster. We now explore whether the stress changes estimated over the representative fault planes of the aftershock clusters could explain the spatial pattern of the aftershocks, the northeastern aftershock cluster in particular. The stress changes over the VF beyond the rupture of 2011 Van earthquake indicate that the mainshock rupture bolstered stress over both the eastern (Fig. 6c) and western (Fig. 6d) continuation of the VF, providing proper conditions for the occurrence of the thrusting aftershocks in the eastern and western clusters. Figure 6e suggests that the mainshock rupture promoted the stress over the EF or over the E-W trending strike-slip faults. However, one of the aftershock with known strike-slip mechanism (number 43 in Table 3 and Fig. 3) fall into stress shadow. Note that this aftershock falls into the area of stress increase in Fig 6a, suggesting that it might have occurred on a strikeslip fault having different orientation than the EF. When the stress changes have been estimated over the planes parallel to the ÇF, NE-SW trending left-lateral fault lying along the NW coast of Lake Van, it is seen that the north eastern cluster falls into the stress shadow (not shown in Fig. 6). This fault also does not match any nodal plane of the available source mechanisms in the north eastern cluster. Therefore, the stress changes have been calculated over the planes running parallel to the right-lateral EFZ (Fig. 6f). The EFZ runs offshore and emerge in the east of NE tip Lake Van (Koçyiğit et al., 2011). Orientation of the EFZ matches well the NW-SE trending nodal plane of the available source mechanisms in the north eastern cluster. Notice that this time the north eastern cluster falls into the area of stress increase (Fig. 6f), suggesting that the mainshock may have triggered aftershocks along the EFZ.

Another observed spatial pattern mentioned above has been that the dense aftershock epicentres cover a much broader area toward NE due to a lobe of aftershock epicentres protruding outward while their southern limit goes roughly parallel regarding surface projection of the mainshock rupture plane (Fig. 4). The stress change maps shown in Fig. 6 provide an answer for this observed pattern. Note that the major faults lying in the north-northeast of the 2011 Van earthquake rupture are strike-slip faults (the EFZ and ÇFZ) while the major faults lying in the south-southeast of the rupture are thrust faults (the GF, SBF and NBF) (Figs. 2 and 3). Figure $6 \mathrm{e}$ and $\mathrm{f}$, in which the stress changes are calculated for E$\mathrm{W}$ and NW-SE trending right lateral strike-slip faults, require a lobe of stress increase in the NE, while the stress changes for thrusting faults (Fig. 6b, c and d) require a large lobe of stress shadow in the south-southeast. The strike-slip faults are secondary in significance in the south-southeast and have experienced partly stress decrease and increase (Fig. 6a, e and f). These results coincide with the results of the previous studies suggesting a relation between the orientation of the mapped structure and the aftershock seismicity following a mainshock (Steacy et al., 2005b; McCloskey and Nalbant, 2009).

\subsection{Implication for the earthquake hazard mitigation}

As indicated above the 1696 Çaldıran and 1715 Van earthquakes most likely recurred as the 1976 Çaldıran and 2011 Van earthquakes, respectively, suggesting an earthquake recurrence time of about $300 \mathrm{yr}$. Considering peak slip of about $4.5-5 \mathrm{~m}$ from the available slip models of both earthquakes (Utkucu et al., 2002; Hayes, 2011; Utkucu, 2013a), a $300 \mathrm{yr}$ recurrence time would yield a comparable slip rate suggested by GPS studies (McClusky et al., 2000; Reilinger et al., 2006), which indicate a velocity of $12 \mathrm{~mm} \mathrm{yr}^{-1}$ toward the north and $5.3 \mathrm{~mm} \mathrm{yr}^{-1}$ toward the west with velocity vector having a direction almost perpendicular to the strike of the VF. Since the 1646 Van earthquake has not yet recurred, the GF with roughly same orientation as the VF has been accumulating elastic deformation or getting stressed for about $350 \mathrm{yr}$, meaning that it capable of producing an event even larger than the 2011 Van earthquake. Fortunately, the GF not only remained in the stress shadow of the 2011 Van earthquake but also of the 1715 Van earthquake. It is not farfetched that one of the reason behind the delaying of the occurrence of the 1646 Van earthquake might have been the stress shadow of both earthquakes along the Van fault, considering the published cases in the past (Toda and Stein, 2002).

With an exception of the 1941 Erciş earthquake $\left(M_{\mathrm{S}}=\right.$ 6.0), we have no information for earthquakes rupturing the EFZ after 1646. The 1941 Erciş earthquake was not large enough to release tectonic deformation along the EFZ, 


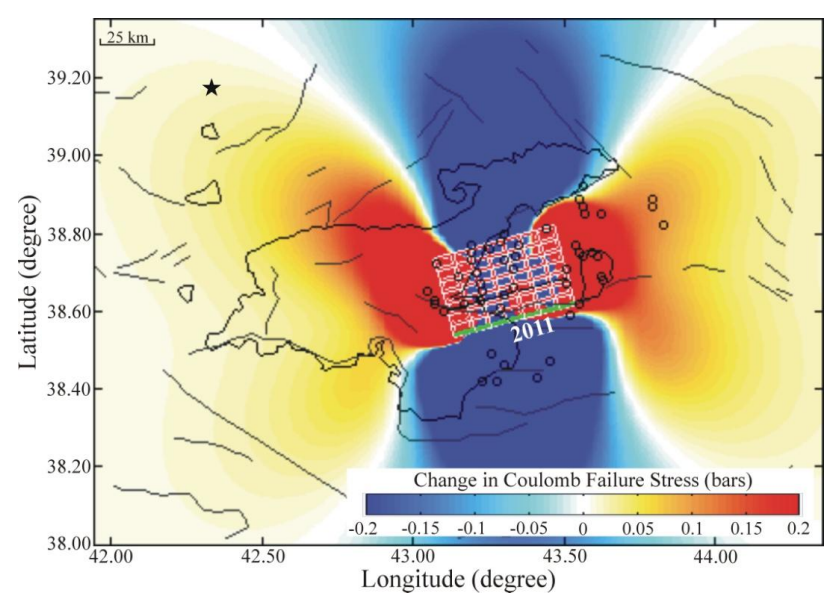

Fig. 7. Coulomb stress changes imparted to the hypocentral area of the 26 March 2012 aftershock $\left(M_{\mathrm{W}}=5.0\right.$; number 50 in Table 3 and is indicated with a black star) due to the 2011 Van earthquake rupture. The stress calculations have been implemented over its north dipping nodal plane (strike $=256^{\circ}$, dip $=46^{\circ}$, rake $=86^{\circ}$ ). The open circles denote the epicentres of the $M \geq 4.6$ aftershocks listed in Table 3. Notice occurrence of this far away aftershock in the stress enhancement area. See caption of Fig. 2 for the active fault references.

meaning the EFZ has not been ruptured at least for the last four centuries. Considering its similarity with ÇFZ, which produced 1976 Çaldıran earthquake, both in orientation and faulting type, the EFZ might have the potential to generate a large shock, likelihood of which seems to increase due to the occurrence of the 2011 Van earthquake (Fig. 6f).

As interpreted from the stress change maps shown in Fig. 6, there is a strong correspondence between the stress perturbations caused by the 2011 Van earthquake and the observed spatial pattern of the aftershock distribution. This advances the use of Coulomb stress change modelling as a tool for aftershock hazard mitigation, especially for the mainshocks with long and damaging aftershock activity like the 2011 Van earthquake. A preliminary stress analysis can simply be performed from the mainshock information available in near-real time in order to guess or interpret upcoming spatial patterns of aftershocks for earthquake hazard mitigation and emergency response purposes. This issue has been elaborately discussed recently in several studies in which a strong coincidence between Coulomb stress changes and the spatial distribution of aftershock has been reported in cases where the stress changes were based on the well-constrained rupture properties and good knowledge of local geological structure (Steacy et al., 2004; Steacy et al., 2005b; McCloskey and Nalbant, 2009). Notice that there is a rare aftershock occurrence in the NW of Lake Van, including the 26 March 2012 aftershock $\left(M_{\mathrm{W}}=5.0\right.$; number 50 in Table 3 and Fig. 3$)$ with thrusting mechanism near the town of Bulanık. A Coulomb stress change map calculated over its north dipping nodal plane $\left(\right.$ strike $=256^{\circ}, \operatorname{dip}=46^{\circ}$, rake $=86^{\circ}$ ) due to the 2011 Van earthquake rupture has shown that this aftershock occurred in the area of stress enhancement (Fig. 7), supporting the apparent correspondence between the mainshock stress changes and the spatial pattern of the aftershock seismicity even for stress changes down to the 0.1 bar. This further bolsters the idea of how the stress change maps would be useful for mitigating earthquake hazard to foresee the most likely locations of the upcoming aftershocks, if such calculations are carried out in near-real time.

\section{Conclusions}

We have studied Coulomb stress changes before and after the 23 October 2011 Van earthquake using available data related to the background and the aftershock seismicity and the likely source faults. The coseismic stress changes of the background seismicity had slightly promoted stress over the rupture plane of the 2011 Van earthquake while it yielded a stress shadow over the GF, which has been argued to produce the 7 April 1646 Van earthquake. It is also discussed that the repetition of the 1646 Van earthquake would be the most likely candidate to strike the Lake Van area in the future, regarding the available information from the historical seismicity. The calculated stress change maps have shown that the occurrence of the 2011 Van earthquake further decreased the stress over the GF meaning further delaying of the successor of the 1646 Van earthquake to strike.

Two possible spatial patterns of the aftershock distribution of the 2011 Van earthquake have been identified. The aftershocks define four clusters regarding their relative location to the mainshock rupture plane and source mechanisms and the area for their dense distribution gets broader toward the northeast. Any correlation between these observed spatial patterns of the aftershocks and the coseismic stress changes imposed by the 2011 Van earthquake alone is searched for by calculating Coulomb stress changes over the optimally oriented strike-slip and thrust faults and over the faults lying close to the mainshock rupture. It is shown that there is an apparent correlation between the stress changes and the observed spatial pattern of the aftershock occurrence supporting use of near-real time estimate of the stress changes as a tool for earthquake hazard mitigation.

Acknowledgements. We acknowledge the contribution of the anonymous reviewers because their careful reviews and comments have significantly improved the manuscript. We are grateful to Kandilli Observatory and Earthquake Research Institute of Boğaziçi University and its staff, Doğan Kalafat in particular, for providing the aftershock seismicity. We thank H. Arman for reading the manuscript. Several figures were created using the Generic Mapping Tools (GMT) developed by Wessel and Smith (1998). This research was funded by Research Fund of the Sakarya University (Project Number: 2012-01-14-005) and was 
partly supported by Scientific and Technological Council of Turkey (TUBITAK) post-doctoral fellowship.

Edited by: B. D. Malamud

Reviewed by: three anonymous referees

\section{References}

Adıyaman, Ö., Chorowicz, J., and Köse, O.: Relationships between volcanic patterns and neotectonics in Eastern Anatolia from analysis of satellite images and DEM, J. Volcanol. Geoth. Res., 85, 17-32, 1998.

AFAD Van Depremi (23 Ekim 2011) Raporu, T. C. Başbakanlık Afet ve Acil Durum Yönetimi Deprem Dairesi Başkanlığı, Ankara, Türkiye, 100 pp., 2011.

Akyüz, S., Zabcı, C., and Sançar, T.: 23 Ekim 2011 Van Depremi Hakkında Ön Rapor, İstanbul Teknik Üniversitesi, İstanbul, Turkey, 19 pp., 2011.

Albini, P., Demircioglu, M. B., Locati, M., Rovida, A., Sesetyan, K., Stucchi, M., and Vigano, D.: In search of the predecessors of the 2011 Van (Turkey) Earthquake, Seismol. Res. Lett., 83, 855-862, doi:10.1785/0220110146, 2012.

Ambraseys, N.: Earthquakes in the Mediterranean and Middle East: A Multidisciplinary Study Of Seismicity up to 1900, Cambridge University Press, 947 pp., ISBN 978-0-521-87292-8, 2009.

Ambraseys, N. N. and Finkel, C.: The Seismicity of Turkey and Adjacent Areas: A Historical Review, 1500-1800, Eren Publication, İstanbul, ISBN 975-7622-38-9, 240 pp., 1995.

Atzori, S., Tolomei, C., Salvi, S., and Zoffoli, S.: Coseismic ground displacement and preliminary source models for the 10/23/2011, $\mathrm{MW}=7.2$, Van earthquake, Eastern Turkey, available at: http:// www.sigris.it/images/stories/SIGRIS-4-Van_1stRep.pdf (last access: 19 June 2013), 2011.

Barka, A. and Kadinsky-Cade, K.: Strike-slip fault geometry in Turkey and its influence on earthquake activity, Tectonics, 7, 663-684, 1988.

CEDIM: Comparing the current impact of the Van Earthquake to past earthquakes in Eastern Turkey, Centre for Disaster Management and Risk Reduction Technology (CEDIM), Forensic Earthquake Analysis Group, Report 4, 28 pp., 2011.

Çelebi, E., Aktaş, M., Çă̆lar, N., Özocak, A., Kutanis, M., Mert, N., and Özcan, Z.: October 23, 2011 Turkey/Van-Erciş earthquake: structural damages in the residential buildings, Nat. Hazards, 65, 2287-2310, doi:10.1007/s11069-012-0478-9, 2013.

Clayton, E.: Earthquake in Van, Nature, 24, p. 238, doi:10.1038/024238b0, 1881.

Emre, Ö., Duman, T. Y., Özalp, S., and Elmacı, H.: 23 Ekim 2011 Van Depremi Saha Gözlemleri ve Kaynak Faya İlişkin Ön Değerlendirmeler, M.T.A Jeoloji Etütler Dairesi, Ankara, Turkey, 22 pp., 2011.

Erdik, M., Kamer, Y., Demircioğlu, M., and Şeşetyan, K.: 23 October 2011 Van (Turkey) earthquake, Nat. Hazards, 64, 651-665, doi:10.1007/s11069-012-0263-9, 2012.

Gülen, L., Utkucu, M., Budakoğlu, E., Yalçın, H. D., Güneş, Y., and Kalafat, D.: Seismotectonics of the Lake Van Region and the 23 October 2011 Van earthquake $\left(M_{W}=7.1\right), 2012$ SSA Annual Meeting, San Diego, Seismol. Res. Lett., 83, p. 438, 2012.

Harris, R. A.: Introduction to special section: Stress triggers, stress shadows, and implification for seismic hazard, J. Geophys. Res.,
103, 24347-24358, 1998.

Hayes, G.: Updated Result of the Oct 23, 2011 Mw 7.1 Eastern Turkey Earthquake, available at: http://earthquake.usgs.gov/ earthquakes/eqinthenews/2011/usb0006bqc/finite_fault.php (last access: 19 June 2013), 2011

Kalafat, D., Güneş, Y., Kara, M., Deniz, P., Kekovalı, K., Kuleli, S. H., Gülen, L., Yılmazer, M., and Özel, N.: A revised and extended earthquake catalogue for Turkey since $1900(M \geq 4.0)$. Boğaziçi University, Kandilli Rasathanesi ve Deprem Araştırma Enstitüsü, Bebek-İstanbul, 553 pp., 2007.

King, G. C. P, Stein, R. S., and Lin, J.: Static Stress Changes and The Triggering Of Earthquakes, B. Seismol. Soc. Am., 84, 935953, 1994.

Koçyiğit, A., Deveci, Ş., and Kaplan, M.: Van Depremleri Raporu (23 Ekim-30 Kasım 2011), Aktif Tektonik ve Deprem Araştırma Laboratuvarı, Orta Doğu Teknik Üniversitesi, Ankara, Türkiye, 22 pp., 2011

Lasocki, S., Karakostas, V. G., and Papadimitriou, E. E.: Assessing the role of stress transfer on aftershock locations, J. Geophys. Res., 114, B11304, doi:10.1029/2008JB006022, 2009.

Lin, J. and Stein, R. S.: Stress triggering in thrust and subduction earthquakes and stress interaction between the southern San Andreas and nearby thrust and strike-slip faults, J. Geophys. Res., 109, B02303, doi:10.1029/2003JB002607, 2004.

Litt, T., Krastel, S., Sturm, M., Kipfer, R., Örçen, S., Heumann, G., Franz, S. O., Ulgen, U. B., and Niessen, F.: "PALEOVAN", International Continental Scientific Drilling Program (ICDP): Site Survey Results and Perspectives, Quaternary Sci. Rev., 28, 15551567, doi:10.1016/j.quascirev.2009.03.002, 2009.

McCloskey, J. and Nalbant, S. S.: Near-real-time aftershock hazard maps, Nat. Geosci., 2, 154-155, 2009.

McClusky, S., Balassanian, S., Barka, A., Demir, C., Ergintav, S., Georgiev, I., Gürkan, O., Hamburger, M., Hurst, K., Kahle, H., Kastens, K., Nadariya, M., Ouzouni, A., Paradissis, D., Peter, Y., Prilepin, M., Reilinger, R., Sanli, I., Seeger, H., Tealeb, A., Toksöz, M. N., and Veis, G.: GPS constraints on plate kinematics and dynamics in the Eastern Mediterranean and Caucasus, J. Geophys. Res., 105, 5695-5719, 2000.

McKenzie, D. P.: Active tectonics of the Mediterranean region, Geophys. J. R. Astr. Soc., 30, 109-185, 1972.

MTA: Türkiye Yenilenmiş Diri Fay Haritası, available at: http://www.mta.gov.tr/v2.0/default.php?id= -yeni_diri_fay_haritalari-goruntule (last access: 19 June 2013), 2012.

Nalbant, S. S., McCloskey, J., Steacy, S., and Barka, A.: Stress accumulation and increased seismic risk in eastern Turkey, Earth Planet Sc. Lett., 195, 291-298, 2002.

Okada, Y.: Internal deformation due to shear and tensile faults in a half-space, B. Seismol. Soc. Am., 82, 1018-1040, 1992.

Parsons, T.: Recalculated probability of $\mathrm{M} \geq 7$ earthquakes beneath the Sea of Marmara, Turkey, J. Geophy. Res., 109, B05304, doi:10.1029/2003JB002667, 2004.

Pinar, A.: Rupture process and spectra of some major Turkish earthquakes and their seismotectonic implications, Ph.D. thesis, Boğaziçi University, 125 pp., İstanbul, 1995.

Pınar, A., Honkura, Y., Kuge, K., Matsushima, M., Sezgin, N., Yllmazer, M., and Ögüutçü, Z.: Source mechanism of the 2000 November 15 Lake Van earthquake $(M \mathrm{w}=5.6)$ in eastern Turkey and its seismotectonic implications, Geophys. J. Int., 170, 
749-763, doi:10.1111/j.1365-246X.2007.03445.x, 2007.

Reilinger, R., McClusky, S., Vernant P., Lawrence, S., Ergintav, S., Cakmak, R., Ozener, H., Kadirov, F., Guliev, I., Stepanyan, R., Nadariya, M., Hahubia, G., Mahmoud, S., Sakr, K., ArRajehi, A., Paradissis, D., Al-Aydrus, A., Prilepin, M., Guseva, T., Evren, E., Dmitrotsa, A., Filikov, S. V., Gomez, F., Al-Ghazzi, R., and Karam, G.: GPS constraints on continental deformation in the Africa-Arabia-Eurasia continental collision zone and implications for the dynamics of plate interactions, J. Geophys. Res., 111, B05411, doi:10.1029/2005JB004051, 2006.

Sandvol, E., Türkelli, N., and Barazangi, M.: The Eastern Turkey Seismic Experiment: The study of a young continent-continent collision: An example from eastern Turkey, Geophys. Res. Lett., 30, 8038, doi:10.1029/2003GL018912, 2003.

Şaroğlu, F.: Doğu Anadolu'nun neotektonik dönemde jeolojik ve yapisal evrimi, Ph.D. thesis, İstanbul University, 240 pp., İstanbul, 1985 (in Turkish).

Şengör, A. M. C., Görür, N., and Şaroğlu, F.: Strike-slip faulting and related basin formation in zones of tectonic escape: Turkey as a case study, in: Strike-slip faulting and basin formation, edited by: Biddle, K. T. and Christie-Blick, N., Soc. Econ. Pa., 37, 227-264, 1985.

Şengör, A. M. C., Özeren, S., Genç, T., and Zor, E.: East Anatolian high plateau as a mantle-supported, north-south shortened domal structure, Geophys. Res. Lett., 30, 8045, doi:10.1029/2003GL017858, 2003.

Sinclair, T.: Two problems concerning the Van Region: Arakel of Tabriz on the earthquake of 1646 and evidence for the rise in the level of the lake, in: Natural Disasters in the Ottoman Empire, edited by: Zachariadou, E., Crete University Press, 207222, 1999.

Steacy, S., Marsan, D., Nalbant, S. S., and McCloskey, J.: Sensitivity of Static Stress Calculations to the Earthquake Slip Distribution, J. Geophys. Res., 109, B04303, doi:10.1029/2002JB002365, 2004.

Steacy, S., Gomberg, J., and Cocco, M.: Introduction to special section: Stress transfer, earthquake triggering, and timedependent seismic hazard, J. Geophys. Res., 110, B05S01, doi:10.1029/2005JB003692, 2005a.

Steacy, S., Marsan, D., Nalbant, S. S., McCloskey, J., Nostro, C., Scotti, O., and Baumont, D.: Onto what planes should Coulomb stress perturbations be resolved?, J. Geophys. Res., 110, B05S15, doi:10.1029/2004JB003356, 2005b.

Stein, R. S.: The Role of Stress in the Earthquake Occurrence, Nature, 402, 605-609, 1999.

Stein, R. S., Barka, A. A., and Dieterich, J. H.: Progressive failure of North Anatolian fault since 1939 by earthquake stress triggering, Geophys. J. Int., 128, 594-604, 1997.

Toda, S. and Stein, R. S.: Response of the San Andreas Fault to the 1983 Coalinga-Nunez earthquakes: An application of interaction-based probabilities for Parkfield, J. Geophys. Res., 107, 2126, doi:10.1029/2001JB000172, 2002.
Toda, S., Stein, R., Richards-Dinger, K., and Bozkurt, S.: Forecasting the evolution of seismicity in southern California: Animations built on earthquake stress transfer, J. Geophys. Res., 110, B05S16, doi:10.1029/2004JB003415, 2005.

Toker, M.: Tectonic and magmatic structure of lake Van Basin and its structural evolution, Eastern Anatolia accretionary complex (eaac), e-turkey, Istanbul Technical University Eurasia Institute of Earth Sciences, 426 pp., 2011.

Üner, S., Yeşilova, Ç., Yakupoğlu, T., and Üner, T.: Earthquake Induced Soft Sediment Deformation Structures (Seismites): Van Gölü Basin, Eastern Anatolia, Journal of the Earth Sciences Application and Research Centre of Hacettepe University, Yerbilimleri, 31, 53-66, 2010.

Utkucu, M.: 23 October 2011 Van, Eastern Anatolia, earthquake $\left(M_{\mathrm{W}}=7.1\right)$ and seismotectonics of Lake Van Area, J. Seismol., 17, 783-805, doi:10.1007/s10950-012-9354-z 2013a.

Utkucu, M., Pınar, A., and Alptekin, Ö.: 24 Kasım 1976 Çaldıran Depremi $(\mathrm{Ms}=7.3)$ İçin Telesismik P Dalga Şekillerinden Ters Çözümünden Elde Edilen Kırılma Modeli, İstanbul Üniv. Müh. Fak. Yerbilimleri Dergisi, 15, 25-36, 2002.

Utkucu, M., Nalbant, S., McClusky, J., Steacy, S., and Alptekin, Ö.: Slip distribution and stress changes associated with the 1999 November 12, Düzce (Turkey) earthquake (Mw=7.1), Geophys. J. Int., 153, 229-241, 2003.

Utkucu, M., Budakoğlu, E., Yalçın, H., Durmuş, H., Kalkan, H., and Gülen, L.: 23 Ekim 2011 Van Depremi $\left(M_{W}=7.2\right)$ Hakkında Ön Rapor, Sakarya Üniversitesi, Sakarya, Turkey, 10 pp., 2011.

Utkucu, M., Budakoğlu, E., Yalçin, H., Durmuş, H., and Gülen, L.: 23 Ekim 2011 Van (Doğu Türkiye) Depremi'nin (Mw=7.1) Sismotektonik Özellikleri, in preparation, 2013b.

Vernant, P., Nilforoushan, F., Hatzfeld, D., Abbasi, M. R., Vigny, C., Masson, F., Nankali, H., Martino, J., Ashtiani, A., Bayer, R., Tavakoli, F., and Chery, J.: Present-day crustal deformation and plate kinematics in the Middle East constrained by GPS measurements in Iran and northern Oman, Geophys. J. Int., 157, 381-398, 2004.

Wells, D. L. and Coppersmith, K. J.: New Empirical Relationships among Magnitude, Rupture Length, Rupture Width, Rupture Area, and Surface Displacement, B. Seismol. Soc. Am., 84, 974-1002, 1994.

Wessel, P. and Smith, W. H. F.: New, improved version of Generic Mapping Tools released, Eos T. Am. Geophys. Un., 79, p. 579, 1998.

Wong, H. K. and Degens, E. T.: The bathymetry of Lake Van, eastern Turkey, in: The Geology Lake Van, No. 169, edited by: Degens, E. T. and Kurtman, F., M.T.A. Press, Ankara, Turkey, 5 pp., 1978.

Wong, H. K. and Finckh, P.: Shallow structure in Lake Van, in: the Geology Lake Van, No. 169, edited by: Degens, E. T. and Kurtman, F., M.T.A. Press, Ankara, Turkey, 1978. 